\title{
"Swiss cheese-like" brain due to Lactobacillus rhamnosus
}

Figure CT scan showing multiple intracerebral hypodensities most likely representing intra-arterial gas as a result of septic emboli due to Lactobacillus rhamnosus

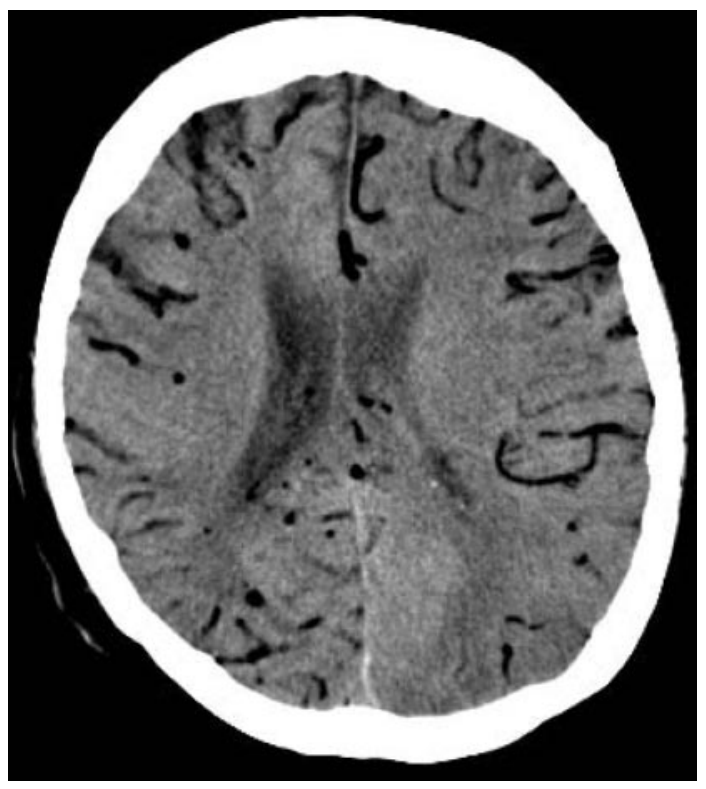

A 69-year-old man presented with acute deterioration of consciousness and tetraparesis. Bacterial endocarditis following mitral valve reconstruction was established 4 weeks prior to the onset of his neurologic deficits. The initial clinical suspicion was of an embolic brainstem infarction. CCT, however, demonstrated multiple intracerebral convoluted tubular hypodensities (figure), most likely representing intra-arterial gas accumulation as a result of multiple septic emboli from bacterial endocarditis. Repeated blood cultures confirmed Lactobacillus rhamnosus, an anaerobic Gram-positive bacillus. The patient died 2 days later despite extensive antibiotic and antimycotic treatment. In addition to bacterial meningoencephalitis further septic emboli leading to infarction of spleen and kidney were identified at autopsy.

Martin Wolz, MD, and Jochen Schaefer, MD, Dresden, Germany

Disclosure: The authors report no conflicts of interest.

Address correspondence and reprint requests to Dr. Martin Wolz, Department of Neurology, Technical University Dresden, Fetscherstrasse 74,01307Dresden,Germany; martin.wolz@uniklinikum-dresden.de 


\title{
Neurology
}

\author{
"Swiss cheese-like" brain due to Lactobacillus rhamnosus \\ Martin Wolz and Jochen Schaefer \\ Neurology 2008;70;979 \\ DOI 10.1212/01.wnl.0000305967.88845.c7
}

\section{This information is current as of March 17, 2008}

\section{Updated Information \& Services}

\section{Subspecialty Collections}

Permissions \& Licensing

Reprints including high resolution figures, can be found at: http://n.neurology.org/content/70/12/979.full

This article, along with others on similar topics, appears in the following collection(s):

Bacterial infections

http://n.neurology.org/cgi/collection/bacterial_infections

\section{CT}

http://n.neurology.org/cgi/collection/ct

Encephalitis

http://n.neurology.org/cgi/collection/encephalitis

Meningitis

http://n.neurology.org/cgi/collection/meningitis

Information about reproducing this article in parts (figures,tables) or in its entirety can be found online at:

http://www.neurology.org/about/about_the_journal\#permissions

Information about ordering reprints can be found online:

http://n.neurology.org/subscribers/advertise

Neurology $®$ is the official journal of the American Academy of Neurology. Published continuously since 1951, it is now a weekly with 48 issues per year. Copyright . All rights reserved. Print ISSN: 0028-3878. Online ISSN: 1526-632X.

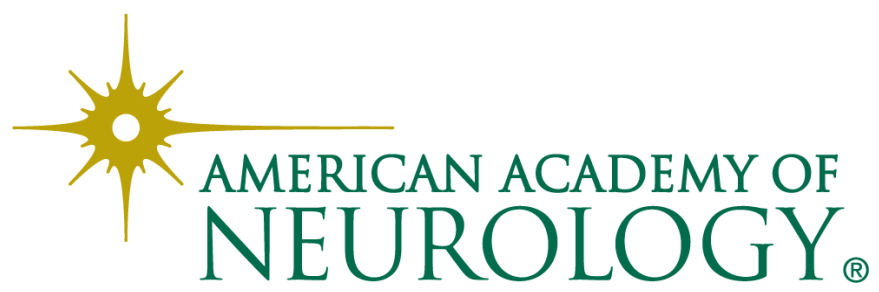

